\title{
ACKNOWLEDGEMENTS
}

For a variety of practical reasons I have consulted few people while writing this book. No one other than myself can therefore be blamed for any shortcomings. However, many people have helped me over the years and without this foundation, the book would have been impossible to write. In particular, I would like to thank: in Czechoslovakia and the Czech and Slovak Republics, the National Film Archive, Prague (Národní filmový archiv), the Slovak Film Institute (Slovenský filmový ústav), Finále Film Festival Plzeň, Karlovy Vary International Film Festival, the Bratislava International Film Festival and the Summer Film School at Písek held in the second part of the 1980s; in United Kingdom, the Slade School of Fine Art at University College London, the British Federation of Film Societies, the National Film Archive, the National Film Theatre London, the Czech Centre London, the London Film Festival, Stoke Film Theatre and Staffordshire University. All have facilitated both access to films and opportunities for study. The opportunity to meet and interview Czech and Slovak directors through my work for the London Film Festival and the Czech Centre London has proved particularly valuable.

I would like to acknowledge the support of those who have encouraged me to write on these subjects over the years, including Birgit Beumers (KinoKultura), Peter Cargin (Film), Andrew James Horton (Kinoeye), Penelope Houston (Sight and Sound), Nick James (Sight and Sound) and Mehelli Modi (Second Run DVD), together with those editors, co-editors and publishers who have supported my previous work: Yoram Allon (Wallflower Press), Ernest Callenbach (University of California Press), Daniel J. Goulding (Oberlin College), Dina 
Iordanova (University of St Andrews), Catherine Portuges (University of Massachusetts, Amherst), and Matthew Stevens (Flicks Books).

I am not listing here the directors and film personalities who I have interviewed. I must however mention all those who have been of key importance in providing practical assistance and insight in different circumstances: Liz-Anne Bawden, Renata Clark, Myrtil Frída, Dana Hábová, Věroslav Hába, Jenny Hames, Nick Hames, Sandra Hebron, Eva Kačerová, L'ubica Mistríková, Vladimír Opěla, David Phillips, Shaun Richards, Zdena Škapová and Miroslav Ulman. Original stills, where it has been possible to identify the photographer, are by Karel Ješátko (The Party and the Guests), Jaromír Komárek (Loves of a Blonde), Jiří Kučera (Cutting it Short), Vladimír Souček (Marketa Lazarová), Zdeněk Tichý (It's Gonna Get Worse) and Vlado Vavrek (Birds, Orphans and Fools). Stills are reproduced with the permission of Karel Ješátko, Jiří Kucera, Vladimír Souček, Zdeněk Tichý, and Athanor Film (Conspirators of Pleasure), Jan Němec Film (Toyen), Krátký Film Praha (An Invention for Destruction), National Film Archive, Prague (Desire), and the Slovak Film Institute, Bratislava (Birds, Orphans and Fools). I would further like to acknowledge the assistance of Athanor Film (Jaromír Kallista, Jan Švankmajer, Pavla Kallistová), Bonton Films (Aleš Novák, David Budský), Jan Němec Film (Jan Němec, Iva Ruszeláková), Krátký Film Praha (Barbora Wohlinová), the National Film Archive, Prague (Vladimír Opěla, Vanda Jarošová, Karel Zima), První veřejnoprávní (Čestmír Kopecký, Anna Kopecká), the Slovak Film Institute (Peter Dubecký, Miroslav Ulman) and the State Fund of the Czech Republic for the Support and Development of Czech Cinematography (Přremysl Huňa).

I would like to thank Linda Badley and R. Barton Palmer for their careful reading of the final text and all those at Edinburgh University Press for their efficient and detailed help and advice: Jackie Jones, Sarah Edwards, James Dale, Patricia Marshall, Máiréad McElligott, and Padmini Ray Murray.

Peter Hames

Stone, Staffordshire

February 2009 
TRADITIONS IN WORLD CINEMA

General Editors

Linda Badley (Middle Tennessee State

University)

R. Barton Palmer (Clemson University)

\section{Founding Editor}

Steven Jay Schneider (New York

University)

Titles in the series include:

Traditions in World Cinema

by Linda Badley, R. Barton Palmer and Steven Jay Schneider (eds)

9780748618620 (hardback)

9780748618637 (paperback)

Japanese Horror Cinema

by Jay McRoy (ed.)

9780748619948 (hardback)

9780748619955 (paperback)

New Punk Cinema

by Nicholas Rombes (ed.)

9780748620340 (hardback)

9780748620357 (paperback)

African Filmmaking: North and South of the Sahara

by Roy Armes

9780748621231 (hardback)

9780748621248 (paperback)

Palestinian Cinema: Landscape, Trauma

and Memory

By Nurith Gertz

9780748634071 (hardback)

9780748634088 (paperback)

Chinese Martial Arts Cinema: The Wuxia

Tradition

By Stephen Teo

9780748632855 (hardback)

9780748632862 (paperback)

Czech and Slovak Cinema: Theme and

Tradition

by Peter Hames

9780748620814 (hardback)
Forthcoming titles include:

The International Film Musical

By Corey K. Creekmur

9780748634767 (hardback)

The Spanish Horror Film

By Antonio Lázaro-Reboll

9780748636389 (hardback)

American Independent-Commercial

Cinema

by Linda Badley and R. Barton Palmer

9780748624591 (hardback)

The Italian Sword-and-Sandal Film

by Frank Burke

9780748619832 (hardback)

Italian Neorealist Cinema

Torunn Haaland

9780748636112 (hardback)

New Nordic Cinema

Mette Hjort

9780748636310 (hardback)

Magic Realist Cinema in East Central

Europe

Aga Skrodzka-Bates

9780748639168 (hardback) 